\title{
The Ecocentrists
}





\section{The Ecocentrists \\ A History of Radical Environmentalism}

Keith Makoto Woodhouse

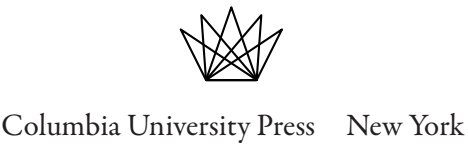


Columbia University Press

Publishers Since 1893

New York Chichester, West Sussex

cup.columbia.edu

Copyright () 2018 Columbia University Press

All rights reserved

Cataloging-in-Publication Data available from the Library of Congress

ISBN 978-0-23I-I6588-4 (cloth)

ISBN 978-0-23I-547I5-4 (e-book)

Columbia University Press books are printed on permanent and durable acid-free paper.

Printed in the United States of America

Cover design: Julia Kushnirsky

Cover photograph: (c) Richard Schultz 